\title{
Lung ultrasound in infants with bronchiolitis
}

\author{
Danilo Buonsenso ${ }^{1,2^{*}} \mathbb{D}$, Anna Maria Musolino ${ }^{3}$, Antonio Gatto ${ }^{1}$, Ilaria Lazzareschi ${ }^{1}$, Antonietta Curatola ${ }^{1}$ and \\ Piero Valentini ${ }^{1,2}$
}

\begin{abstract}
Lung ultrasound (LUS) is nowadays a fast-growing field of study since the technique has been widely acknowledged as a cost-effective, radiation free, and ready available alternative to standard X-ray imaging. However, despite extensive acoustic characterization studies and documented medical evidences, a lot is still unknown about how ultrasounds interact with lung tissue. One of the most discussed lung artifacts are the B-lines [in all ages] and the subpleural consolidations (in young infants). Recently, LUS has been claimed to be able to detect pneumonia in infants with bronchiolitis, although this can be an overestimation due to the peculiar physiology of small peripheral airways of the pediatric lung (particularly in neonate/infants). Distinguishing consolidations from atelectasis in young infants with bronchiolitis can be challenging and those criteria well defined for adults and older children (size and bronchogram) cannot easily translated in this specific subset. Therefore, if decades of studies clearly defined the low risk of SBI in bronchiolitis, we need to be careful before stating that LUS may confirm pneumonia in such a high number of cases and, importantly, new and promising techniques such as LUS should give us new insights bringing us to improvements and not back to overuse of antibiotics. More studies are surely need on this topic.
\end{abstract}

Keywords: Lung ultrasound, Pneumonia, Bronchiolitis, Infants, Children, Precision medicine, Personalized medicine, Radiomics

\section{To the editor}

We read with interest the manuscript "Lung ultrasound for the diagnosis of pneumonia in children with acute bronchiolitis" by Biagi et al. [1].

The study, methodologically well done, evaluated 87 children with bronchiolitis of which 25 (29\%) received a final diagnosis of concomitant pneumonia made by both lung ultrasound (LUS) and chest X-ray (CXR), with a high concordance between the techniques. This is a hot topic since this represents a common diagnostic dilemma for the paediatrician and therefore deserves attention. Sensitivity and specificity of LUS for the diagnosis of pneumonia were 100 and $83.9 \%$ respectively, wsith an area under-the-curve of 0.92 , while CXR showed a sensitivity of $96 \%$ and specificity of $87.1 \%$. When only consolidations $>1 \mathrm{~cm}$ were considered consistent with pneumonia, LUS specificity increased to $98.4 \%$ and the sensitivity decreased to 80.0 .

\footnotetext{
* Correspondence: danilobuonsenso@gmail.com

${ }^{1}$ Fondazione Policlinico Universitario A. Gemelli, IRCCS, Rome, Italy

${ }^{2}$ Universita Cattolica del Sacro Cuore, Roma, Italy

Full list of author information is available at the end of the article
}

Interestingly, as shown in Table 1 of Biagi's manuscript [1], the 25 children with pneumonia were all those patients with moderate to severe bronchiolitis clinical score.

Stating that about $1 / 3$ of patients with bronchiolitis have pneumonia and all those with moderate to severe bronchiolitis clinical score have concomitant pneumonia, represents a strong message that brings the potential risk of importantly rise the indiscriminate use of antibiotics in infants with bronchiolitis. This is a message that need clarifications, particularly in the era of the dangerous increase of antimicrobial resistance and renewed importance of antibiotic stewardship.

Important clinical studies, including 1 randomized trial, suggested that children with suspected lower respiratory tract infection who underwent radiography were more likely to receive antibiotics without any difference in outcomes $[2,3]$. The American Academy of Pediatrics (AAP) [4], in fact, states that CXR should be reserved for severe cases needing intensive care unit admission or where signs of an airway complication (such as pneumothorax) are present.

(c) The Author(s). 2019 Open Access This article is distributed under the terms of the Creative Commons Attribution 4.0 International License (http://creativecommons.org/licenses/by/4.0/), which permits unrestricted use, distribution, and reproduction in any medium, provided you give appropriate credit to the original author(s) and the source, provide a link to the Creative Commons license, and indicate if changes were made. The Creative Commons Public Domain Dedication waiver (http://creativecommons.org/publicdomain/zero/1.0/) applies to the data made available in this article, unless otherwise stated. 
Despite randomized controlled trials [5, 6] showed no benefit from routine antibacterial therapy for children with bronchiolitis, antibiotic therapy continues to be overused in young infants with bronchiolitis because of concern for fever [7], young age [8] and secondary bacterial infection [9]. Studies [10, 11] have shown that a child with a clear viral syndrome, such as bronchiolitis, has a much less than $1 \%$ risk of serious bacterial infection (SBI) concluding that routine screening for SBI among hospitalized febrile infants with bronchiolitis is not justified. Several retrospective studies [12-18] and four prospective studies of SBI in bronchiolitis and/or respiratory syncytial virus (RSV) infections also confirmed this [19-23].

Therefore, general literature is much distant from the article by Biagi et al. [1]. Nevertheless, considering the LUS use in this condition, we want to share our experience in LUS in infants with bronchiolitis to further reply.

We agree with Biagi et al. [1] with the potential role of LUS in bronchiolitis; in our experience we are having opposite results that remark the usefulness need for antibiotic in these patients and that LUS may be important in rulingout pneumonia instead of confirming it from doubtful CXR.

We already published 3 articles on LUS in bronchiolitis [24-26] and we found no cases of pneumonia in these children, despite we evaluated 138 cases in the two published series.

Moreover, we are now part of an Italian multicentric study on this issues whose results will be available in about 2 years.

We are now routinely following up on an almost daily base infants with bronchiolitis through LUS. This is part of a study approved by the Institutional Review Board of our institution, and written informed consent was obtained by both parents of our patients. To reply Biagi et al., we report the last 20 cases of RSV confirmed bronchiolitis evaluated during this ongoing epidemic season. $100 \%$ of these patients had subpleural consolidations and air bronchogram was described in $19 \%$ of cases, and almost all patients [96\%] had consolidations located in the posterior paravertebral area; importantly, these consolidations sometimes disappeared the day after and in other cases persisted (although slightly reduced in size) up to 5-7 days after the first LUS independently from which treatment was performed (from high-flow nasal cannulae to antibiotics to steroids) or no treatment at all started. Most patients had a positive CXR according to the radiology on duty (Fig. 1, cases 1 to 4). LUS findings were similar despite fever and $\mathrm{C}$-reactive protein levels. In one case we diagnosed a concomitant pneumonia and a microbiological confirmation of $H$. influenza pneumonia was obtained (Fig. 1, case 5). The child also had $37,070 / \mathrm{mmc}$ white blood cells with 20 , $870 / \mathrm{mmc}$ neutrophils and C-reactive protein 5 times higher than threshold. Interestingly, LUS appearance of

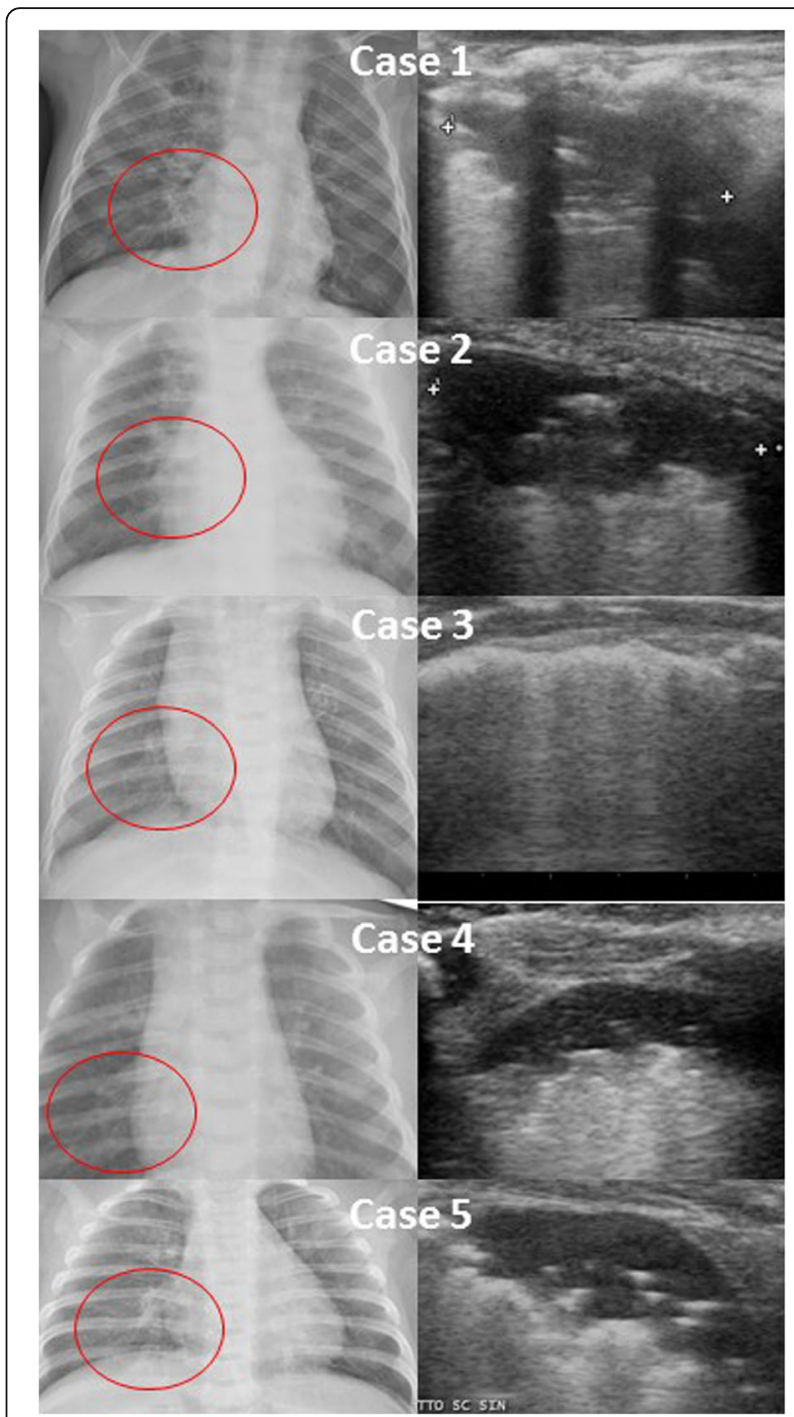

Fig. 1 A case series of paracardiac consolidations on chest X-ray and the corresponding pattern on lung ultrasound, showing posterior, paravertebral, subpleural consolidations

this case was similar to the other non-complicated cases. This highlight that LUS semeiotic in young infants still need to be studied and clarified and that clinical findings are important for the proper interpretation of LUS findings. In our experience, whenever we face with CXR suspected for pneumonia in an infant with bronchiolitis (usually requested by paediatricians not experienced in LUS), we perform LUS to rule-out pneumonia and we are extensively reducing the use of antibiotics, as suggested by the AAP [4]. Only with extensive consolidations and abnormal laboratory findings we diagnose a concomitant pneumonia. We think these data need to be considered otherwise other paediatricians could be keep using indiscriminate empirical antibiotics in bronchiolitis.

"LUS is nowadays a fast-growing field of study" since the technique has been widely acknowledged as a cost- 
effective, radiation free, and ready available alternative to standard X-ray imaging [1]. However, despite extensive acoustic characterization studies [27-33] and documented medical evidences [34-44], a lot is still unknown about how ultrasounds interact with lung tissue [45]. One of the most discussed lung artifacts are the B-lines [in all ages] and the subpleural consolidations (in young infants). For example, to further study B-lines, Demi et al. [45] developed lung-phantoms by trapping a layer of microbubbles in tissue-mimicking gel. They demonstrated how the frequency of B-lines could provide a quantitative-measure of the state of the lung but, on the other hand, also highlights the heterogeneity of artefacts.

The reason for our hypothesis is that the small peripheral airways of the pediatric lung (particularly in neonate/ infants) can easily change during physiological breathing and have peculiar changes during pathology. Distinguishing consolidations from atelectasis in young infants with bronchiolitis can be challenging and those criteria well defined for adults and older children (size and bronchogram) cannot easily translated in this specific subset. Therefore, if decades of studies clearly defined the low risk of SBI in bronchiolitis, we need to be careful before stating that LUS may confirm pneumonia in such a high number of cases and, importantly, new and promising techniques such as LUS should give us new insights bringing us to improvements and not back to overuse of antibiotics. More studies are surely need on this topic.

\section{Abbreviations}

AAP: American Academy of Pediatrics; CXR: Chest X-ray; LUS: Lung ultrasound; RSV: Respiratory syncytial virus; SBI: Serious bacterial infection

\section{Acknowledgements}

We acknowledge dr. Paolo Tomà and Gino Soldati for constant inspiration for practicing and improving in the field of lung ultrasound.

\section{Authors' contributions}

$D B$ and $A M$ performed lung ultrasound and conceptualized the study. AC perfmormed lung ultrasound. AG, IL, PV took care of patients. DB, AM, PV wrote and edited the manuscript. All authors gave final approval.

\section{Funding}

No funding obtained.

\section{Availability of data and materials}

The datasets used and/or analysed during the current study are available from the corresponding author on reasonable request.

\section{Ethics approval and consent to participate}

Obtained by the Institutional Review Board of the Fondazione Policlinico Universitario A. Gemelli IRCCS, Roma, Italia; written informed consent was obtained by both parents of our patients.

\section{Consent for publication}

Not applicable.

\section{Competing interests}

The authors declare that they have no competing interests.

\section{Author details}

${ }^{1}$ Fondazione Policlinico Universitario A. Gemelli, IRCCS, Rome, Italy.

${ }^{2}$ Universita Cattolica del Sacro Cuore, Roma, Italy. ${ }^{3}$ Department of Pediatric

Emergency, Bambino Gesu Children's Hospital, IRCCS, Rome, Italy.

Received: 31 January 2019 Accepted: 19 August 2019

Published online: 24 August 2019

\section{References}

1. Biagi C, Pierantoni L, Baldazzi M, Greco L, Dormi A, Dondi A, Faldella G, Lanari M. Lung ultrasound for the diagnosis of pneumonia in children with acute bronchiolitis. BMC Pulm Med. 2018;18:191

2. Swingler GH, Hussey GD, Zwarenstein M. Randomised controlled trial of clinical outcome after chest radiograph in ambulatory acute lowerrespiratory infection in children. Lancet. 1998:351:404-8.

3. Schuh S, Lalani A, Allen U, Manson D, Babyn P, Stephens D, MacPhee S, Mokanski M, Khaikin S, Dick P. Evaluation of the utility of radiography in acute bronchiolitis. J Pediatr. 2007;150:429-33.

4. Ralston SL, Lieberthal AS, Meissner HC, Alverson BK, Baley JE, Gadomski AM, Johnson DW, Light MJ, Maraqa NF, Mendonca EA, Phelan KJ, Zorc JJ, Stanko-Lopp D, Brown MA, Nathanson I, Rosenblum E, Sayles S 3rd, Hernandez-Cancio S. American Academy of Pediatrics. Clinical practice guideline: the diagnosis, management, and prevention of bronchiolitis. Pediatrics. 2014;134:e1474-502.

5. Friis B, Andersen P, Brenøe E, Hornsleth A, Jensen A, Knudsen FU, Krasilnikoff PA, Mordhorst CH, Nielsen S, Uldall P. Antibiotic treatment of pneumonia and bronchiolitis. A prospective randomised study. Arch Dis Child. 1984;59: 1038-45.

6. Greenes DS, Harper MB. Low risk of bacteremia in febrile children with recognizable viral syndromes. Pediatr Infect Dis J. 1999;18:258-61.

7. Nichol KP, Cherry JD. Bacterial-viral interrelations in respiratory infections of children. N Engl J Med. 1967;277:667-72.

8. Field CM, Connolly JH, Murtagh G, Slattery CM, Turkington EE. Antibiotic treatment of epidemic bronchiolitis—a double-blind trial. BMJ. 1966;1:83-5.

9. Antonow JA, Hansen K, McKinstry CA, Byington CL. Sepsis evaluations in hospitalized infants with bronchiolitis. Pediatr Infect Dis J. 1998;17(3):231-6.

10. Spurling GK, Doust J, Del Mar CB, Eriksson L. Antibiotics for bronchiolitis in children. Cochrane Database Syst Rev. 2011;(6):CD005189.

11. Ralston $\mathrm{S}$, Hill V, Waters $A$. Occult serious bacterial infection in infants younger than 60 to 90 days with bronchiolitis: a systematic review. Arch Pediatr Adolesc Med. 2011;165:951-6.

12. Purcell K, Fergie J. Concurrent serious bacterial infections in 2396 infants and children hospitalized with respiratory syncytial virus lower respiratory tract infections. Arch Pediatr Adolesc Med. 2002;156:322-4.

13. Purcell K, Fergie J. Concurrent serious bacterial infections in 912 infants and children hospitalized for treatment of respiratory syncytial virus lower respiratory tract infection. Pediatr Infect Dis J. 2004;23:267-9.

14. Kuppermann N, Bank DE, Walton EA, Senac MO Jr, McCaslin I. Risks for bacteremia and urinary tract infections in young febrile children with bronchiolitis. Arch Pediatr Adolesc Med. 1997;151:1207-14.

15. Titus MO, Wright SW. Prevalence of serious bacterial infections in febrile infants with respiratory syncytial virus infection. Pediatrics. 2003;112:282-4.

16. Melendez $\mathrm{E}$, Harper MB. Utility of sepsis evaluation in infants 90 days of age or younger with fever and clinical bronchiolitis. Pediatr Infect Dis J. 2003;22: 1053-6.

17. Hall CB, Powell KR, Schnabel KC, Gala CL, Pincus PH. Risk of secondary bacterial infection in infants hospitalized with respiratory syncytial viral infection. J Pediatr. 1988;113:266-71.

18. Hall CB. Respiratory syncytial virus: a continuing culprit and conundrum. J Pediatr. 1999;135(2 pt 2):2-7.

19. Davies HD, Matlow A, Petric M, Glazier R, Wang EE. Prospective comparative study of viral, bacterial and atypical organisms identified in pneumonia and bronchiolitis in hospitalized Canadian infants. Pediatr Infect Dis J. 1996;15:371-5.

20. Levine DA, Platt SL, Dayan PS, et al. Multicenter RSV-SBI study Group of the Pediatric Emergency Medicine Collaborative Research Committee of the American Academy of Pediatrics. Risk of serious bacterial infection in young febrile infants with respiratory syncytial virus infections. Pediatrics. 2004;113:1728-34.

21. Kellner JD, Ohlsson A, Gadomski AM, Wang EE. Bronchodilators for bronchiolitis. Cochrane Database Syst Rev. 2000;(2):CD001266.

22. Pinto LA, Pitrez PM, Luisi F, et al. Azithromycin therapy in hospitalized infants with acute bronchiolitis is not associated with better clinical 
outcomes: a randomized, double-blinded, and placebocontrolled clinical trial. J Pediatr. 2012;161:1104-8.

23. McCallum GB, Morris PS, Chang AB. Antibiotics for persistent cough or wheeze following acute bronchiolitis in children. Cochrane Database Syst Rev. 2012;(12):CD009834.

24. Buonsenso D, Supino MC, Giglioni E, Battaglia M, Mesturino A, Scateni S, Scialanga B, Reale A, Musolino AMC. Point of care diaphragm ultrasound in infants with bronchiolitis: a prospective study. Pediatr Pulmonol. 2018:53:778-86.

25. Buonsenso D, Musolino A. Point of care diaphragm ultrasound in infants with bronchiolitis. Pediatr Pulmonol. 2018:53:1597.

26. Supino Point-of-Care lung ultrasound in infants with bronchiolitis in the pediatric emergency department: a prospective study. European Journal of Pediatrics. In press.

27. Volpicelli GEM, Blaivas M, Lichtenstein DA, Mathis G, Kirkpatrick AW, Melniker L, Gargani L, Noble VE, Via G, Dean A, Tsung JW, Soldati G, Copetti R, Bouhemad B, Reissig A, Agricola E, Rouby JJ, Arbelot C, Liteplo A, Sargsyan A, Silva F, Hoppmann R, Breitkreutz R, Seibel A, Neri L, Storti E, Petrovic T. International Liaison Committee on Lung Ultrasound (ILC-LUS) for International Consensus Conference on Lung Ultrasound (ICC-LUS). International Liaison Committee on Lung Ultrasound [ILC-LUS] for the International Consensus Conference on Lung Ultrasound [ICC-LUS], International evidence-based recommendations for point-of-care lung ultrasound. Intensive care medicine. 2012:38, 577-591.

28. Dunn F, Fry WJ. Ultrasonic absorption and refection by lung tissue. Phys Med Biol. 1961;5:401-10

29. Bauld TJ, Schwan HP. Attenuation and refection of ultrasound in canine lung tissue. J Acoust Soc Am. 1974;56:1630-7.

30. Pedersen PC, Ozcan HS. Ultrasound properties of lung tissue and their measurements. Ultrasound Med Biol. 1986;12:483-99.

31. Dunn F. Attenuation and speed of ultrasound in lung: dependence upon frequency and infation. J Acoust Soc Am. 1986;80:1248-50.

32. Dunn F. Attenuation and speed of ultrasound in lung. J Acoust Soc Am. 1986:56.1638-9.

33. Mikhak Z, Pedersen PC. Acoustic attenuation properties of the lung: an open question. Ultrasound Med Biol. 2002;28:1209-16.

34. Soldati G, Demi M, Inchingolo R, Smargiassi A, Demi L. On the physical basis of pulmonary sonographic interstitial syndrome. J Ultrasound Med. 2016;35: 2075-86.

35. Jambrik Z, Monti S, Coppola V, Agricola E, Mottola G, Miniati M, Picano E. Usefulness of ultrasound lung comets as non-radiologic sign of extravascular lung water. Am J Cardiol. 2004;93:1265-70.

36. Gargani L, Frassi F, Soldati G, Tesorio P, Gheorghiade M, Picano E. Ultrasound lung comets for diferential diagnosis of acute cardiogenic dyspnea: a comparison with natriuretic peptides. Eur J Heart Fail. 2008;10: 70-7.

37. Reissig A, Kroegel C. Transthoracic sonography of diffuse parenchymal lung disease. J Ultrasound Med. 2003;22:173-80.

38. Volpicelli G, Mussa A, Garofalo G, Cardinale L, Casoli G, Perotto F, Fava C, Frascisco M. Bedside lung ultrasound in the assessment of alveolar interstitial syndrome. Am J Emerg Med. 2006;24:689-96.

39. Copetti R, Soldati G, Copetti P. Chest sonography: a useful tool to diferentiate acute cardiogenic pulmonary edema from acute respiratory distress syndrome. Cardiovasc Ultrasound. 2008;6:6-16.

40. Volpicelli G, Frascisco MF. Sonographic detection of radio-occult interstitial lung involvement in measles pneumonitis. The American Journal of Emergency Medicine. 2009;27:128.e1-3.

41. Soldati G, Testa A, Silva FR, Carbone L, Portale G, Silveri NG. Chest ultrasonography in lung contusion. Chesst. 2006;130:533-8.

42. Soldati G, Smargiassi A, Inchingolo R, Sher S, Nenna R, Valente S, Inchingolo $C D$, Corbo GM. Lung ultrasonography may provide an indirect estimation of lung porosity and airspace geometry. Respiration. 2014;88:548-468.

43. Lichtenstein D, Meziere G, Biderman P, Gepner A, Barre O. The comet-tail artifact. An ultrasound sign of alveolar-interstitial syndrome. Am J Respir Crit Care Med. 1997;156:1640-6.

44. Lichtenstein D, Meziere G, Seiltz J. The dynamic air bonchogram. A lung ultrasound sign of alveolar consolidation ruling out atelectasis. Chest. 2009; 135:421-5.

45. Demi L, van Hoeve W, van Sloun RJG, Soldati G, Demi M. Determination of a potential quantitative measure of the state of the lung using lung ultrasound spectroscopy. Sci Rep. 2017;7:12746.

\section{Publisher's Note}

Springer Nature remains neutral with regard to jurisdictional claims in published maps and institutional affiliations.

\section{Ready to submit your research? Choose BMC and benefit from:}

- fast, convenient online submission

- thorough peer review by experienced researchers in your field

- rapid publication on acceptance

- support for research data, including large and complex data types

- gold Open Access which fosters wider collaboration and increased citations

- maximum visibility for your research: over $100 \mathrm{M}$ website views per year

At BMC, research is always in progress.

Learn more biomedcentral.com/submissions 